\title{
The Impact of Offshoring on Home Country's Employment
}

\author{
Rosa Forte ${ }^{1}$ \\ Rúben Ribeiro ${ }^{2}$
}

\begin{abstract}
Although not a recent phenomenon, offshoring has assumed increasing importance in terms of multinational enterprises' activities, often being the subject of discussion at the political level, especially in more economically developed countries, which tend to suggest that this phenomenon underlies the poor performance of job creation in these economies, contributing to the relocation of jobs. Despite the increasingly numerous and comprehensive studies, findings insist on presenting rather different ideas concerning the effects on home countries' employment. Therefore, taking into account the lack of relevant work in this area focused on the Portuguese reality, it is pertinent to bridge this gap, positively contributing to the enrichment of the existing literature and to a better understanding of the effects of offshoring on employment in Portugal. Based on a sample of 14 sectors of the manufacturing industry during the 1995-2009 period, our results suggest that offshoring has a positive but small impact on home country's employment in the Portuguese case. This result may indicate that due to higher sales induced by productivity gains from offshoring, this contributes to the creation of a greater number of jobs than those who are relocated abroad.
\end{abstract}

\section{Keywords}

Offshoring. International sourcing. Outsourcing. FDI. Employment.

\section{Resumo}

Apesar de não ser um fenômeno recente, o offshoring assume uma importância cada vez maior nas atividades das empresas multinacionais, sendo frequentemente tema de discussão no plano político, principalmente entre economias mais desenvolvidas, devido às associações que Ihe são habitualmente feitas de ser o fenômeno que está na base do fraco desempenho da criação de emprego nestas economias, pelo deslocamento de postos de trabalho. Apesar de estudos cada vez mais numerosos e completos, as conclusões insistem em apresentar ideias bastante díspares sobre o real efeito do offshoring no emprego no país de origem. Desta forma, e considerando a falta de estudos relevantes com foco na realidade portuguesa, torna-se pertinente preencher esta lacuna, contribuindo positivamente para a literatura existente e buscando identificar quais os efeitos empíricos do offshoring no emprego em Portugal.

\footnotetext{
${ }^{1}$ Assistant Professor - Faculdade de Economia - Universidade do Porto, and CEF.UP - Rua Dr. Roberto Frias, 4200 - 464 Porto - Email: rforte@fep.up.pt. - ORCID: http://orcid.org/000-0002-3441-9112

2 Postgraduate student - Faculdade de Economia - Universidade do Porto - Rua Dr. Roberto Frias, 4200 - 464 Porto - Email: ruben.dribeiro@gmail.com - ORCID: http://orcid.org/0000-0001-7774-9456 Recebido: 22/02/2018. Aceite: 29/04/2019.
}

(c) (i) (\$) Esta obra está licenciada com uma Licença Creative Commons Atribuição-Não Comercial 4.0 Internacional. 
Com base numa amostra de 14 setores da indústria transformadora durante o período 19952009, os nossos resultados sugerem que o deslocamento tem um impacto positivo, mas reduzido, no emprego do país de origem no caso português. Esse resultado indica que o número de empregos criados devido às maiores vendas induzidas por ganhos de produtividade resultantes do offshoring mais do que compensa a redução de empregos decorrentes do deslocamento de algumas atividades de produção para o exterior.

\section{Palavras-Chave}

Offshoring. Sourcing internacional. Outsourcing. IDE. Emprego

\section{Introduction}

International sourcing has become increasingly important over the last decades, with multiple examples of companies moving stages of their production process abroad, either through subcontracting to independent suppliers or through the establishment of own production units, that is foreign direct investment (FDI) (Geishecker 2006). This is a phenomenon that can be considered common in the current landscape of activity, strategy and business operations of multinational corporations (Nguyen and Lee, 2008), covering both industrial production and the service sector.

Subcontracting or outsourcing can be defined as the acquisition of inputs from an external supplier, which can either be an entity resident in the same country as the company that subcontracts or can be located abroad (Horgos 2009). However, it is the international character and the use of components produced abroad which usually raises more intense discussions, both in terms of public opinion and in the field of economic research (Horgos 2009). It is here that the term offshoring, which appears in the literature often associated with outsourcing, is highlighted, being often described as an international fragmentation, vertical specialization and international outsourcing (Michel and Rycx 2012). Anyway, "All these terms stand for a common phenomenon: the splitting up of the production process into many separate activities and the shift of some of these activities abroad." (Michel and Rycx 2012, 230). 
So, with the growing popularity of offshoring or international sourcing (Alajääskö 2009), it is important to understand why so many companies increasingly resort to this solution, but especially to understand and verify the consequences for the domestic labour market of the company that uses this strategy.

Regarding the motives to use international sourcing, the existing literature seems to point to a consensus. Neureiter and Nunnenkamp (2010) report that, in general, the reasons to resort to international sourcing (which, as has already been mentioned, encompasses both international outsourcing or the use of foreign subsidiaries) are the reduction of costs and search for new markets and resources. Doh (2005) associates the concept of offshoring to the eclectic paradigm of Dunning, considering that that phenomenon corroborates the above mentioned paradigm, while at the same time, also challenges it. The location, being a decisive factor for the strategies of market and resources seeking and cost reduction, usually taken as the base motivations of international sourcing, will be an equally important factor in the context of this phenomenon (Doh 2005). Alajäskö et al. (2011) also identify all these motives as the driving forces of international sourcing. However, they stress that the most important of all motivations of multinational companies is to reduce costs in order to increase the efficiency of activity by reducing the costs of labour and production. This is a particularly strong trend in companies that look to Asia, particularly China and India, as targets of its international sourcing (Alajääskö et al. 2011).

The relocation of activities from the domestic country to a foreign country (either by appealing to outsourcing or by conducting FDI) lead from the outset, to changes in the labour market. In this context, there is a widespread perception, particularly in the United States (and other developed economies), that structural changes in the employment field regarding the productive sector, in which there has been a reduction of almost 6 million jobs between 2000 and 2010, are due to new technologies, competition from foreign companies and also from the offshoring of production and services by American companies (Dey et al. 2012). However, there are also studies that point to the sense that potential problems faced by certain sectors of developed countries, notably the loss of jobs, have little or nothing to do with the phenomenon of offshoring when we compare its effect with the dynamics and turnover inherent to the labour market (Michel and Rycx 2012), in the sense that the decreased levels of employment are usually compensated for, even partially, by the creation of new 
jobs in the economy (Neureiter and Nunnenkamp 2010). According to the OECD (2007), studies show that offshoring is responsible for only a tiny percentage of all jobs destroyed. Thus, according to the European Monitoring Centre on Change (EMCC), "international relocation is responsible for less than 5\% of the jobs lost in Europe, far behind the bankruptcies, closures and restructuring" (OECD 2007, 117). In the same vein, Crinò's (2009) study is based on the existing empirical literature and asserts that the effects of offshoring on the home country labour market are most visible in groups of workers with lower qualifications (especially in international sourcing of services), being modest the overall impact of this phenomenon. However, it is noteworthy that the offshoring of production of materials / industrial goods appears to increase the volatility of the labour market, i.e., makes the labour demand more elastic and increases the risk of loss of jobs, but does not mean that they are effectively lost (Crinò 2009).

Thus, this paper analyses the effects on the home country labour market (in this case, Portugal) of the firms that are relocating their production, or part of it to another country, under a strategy framed in the phenomenon of offshoring or international sourcing, particularly focusing on the effects of offshoring on employment creation or destruction. Therefore, taking into account the lack of relevant work in this area focused on the Portuguese economy, it is pertinent to try to pave the way to fill this gap, positively contributing to the enrichment of the existing literature and to a better understanding of the effects of international sourcing on the Portuguese economy.

The paper is organized as follows. Section 2 begins by making an approach to the existing literature considered relevant to contextualize the phenomenon of offshoring and the respective effects on the labour market, in particular its effects on job creation and destruction. Section 3 presents the methodology used. In Section 4 we present and discuss the empirical results. Finally we present the main conclusions. 


\section{Literature Review}

\subsection{Offshoring and the Labour Market - Effects on the Job Creation and Destruction}

The concepts of international sourcing or offshoring, outsourcing, offshore outsourcing or international outsourcing are often the target of a superficial approach that assumes them as synonyms or as interchangeable terms when the goal is to qualify the act of a company relocating a particular production process abroad. In this work we adopt the definition by UNCTAD (2004, 148. The term offshoring is used when production is carried out abroad, whether by a subsidiary of the company (FDI) or another company - a local firm or a subsidiary of another multinational company (offshore outsourcing). In short, international outsourcing or offshore outsourcing only apply to cases where production materialized abroad is performed by an external entity to the company (a local firm or a subsidiary of another multinational company), and this is the definition that is followed in the scope of this work.

The relocation of production from developed countries to other countries, especially emerging economies, has been the subject of much discussion, to the extent that over time a negative connotation with offshoring has become widespread in public opinion. This supports the idea that this phenomenon is largely responsible for the decline in employment rates in many developed countries (Linares-Navarro et al. 2009), particularly with regard to unskilled workers. Effectively, the idea that offshoring brings great benefits to producers and consumers has grown, while costs fall disproportionately on workers, especially those with lower levels of qualifications (Hijzen and Swaim 2007). And this is an assumption that is not unreasonable, in that, according to the Heckscher-Ohlin model, when, via outsourcing, highly dependent processes of unskilled labour are delocalized (typically to countries with lower wages and an abundant labour force), the relative demand for unskilled labour in the country that relocates will decrease (hurting low-skilled workers) and the relative demand for skilled labour will increase (Ahn et al., 2008). And there are indeed studies that support this view.

Strauss-Kahn (2004) states that vertical specialization, and the consequent offshoring of certain stages of production, contributed significantly to the observed decline in the number of unskilled jobs relative to more skilled 
jobs in French industry in the 1977-1993 period. However, other factors also contributed to the growing demand for skilled labour, including technological progress, which is probably the strongest reason for the decline in demand for unskilled labour (Strauss-Kahn, 2004). Similarly, Geishecker (2006) considers that international sourcing is effectively an explanatory and contributing factor to the decline in demand for workers in areas that require low skills in the context of German industrial production (manual workers). In other words, offshoring affects the demand for unskilled labour, benefiting the skill upgrading in the labour market. Differentiating between outsourcing towards Central and Eastern European countries (CEEC), the EU15 member states and the rest of the world, the authors concluded that "Particularly, outsourcing towards CEEC plays a major role, irrespective of whether a narrow or wide measure of outsourcing is applied" (Geishecker 2006, 580).

Cadarso et al. (2008), in a study focusing on the effects of offshoring on employment generated by 92 Spanish industrial sectors, concluded that there is a negative effect of offshoring on employment (job destruction) in technologically more advanced sectors, not getting a clear effect of international sourcing in low technology sectors. Cadarso et al. $(2008,107)$ argue that "Outsourcing can decrease the demand not only for low-skilled labour but also some types of skilled labour that is cheaper abroad". Similarly to Geishecker (2006), Cadarso et al. (2008) also differentiated between different geographical locations (the EU15 and CEEC) concluding that outsourcing seems to have a negative impact on the level of employment, particularly in the case of outsourcing to CEEC.

Liu and Nunnenkamp (2011), in a study based on firm-specific data on Taiwanese multinational firms (MNEs), indicate that the likelihood of negative effects on domestic production and employment increases with the importance of the activity of the foreign subsidiaries of Taiwanese MNEs, so some of the concerns raised by public opinion are justified. According to the authors, FDI has a negative impact on a home country's production and employment and the probability of negative effects increases with the relative scale of FDI that is with the relative importance of foreign subsidiaries in total operations of the Taiwanese companies. Furthermore, the authors also concluded that the location of FDI influences the type of effects found: FDI in mainland China tend to have a negative impact on domestic production and employment while FDI in advanced host countries has a positive effect on domestic production although the effect on employment is not statistically significant. 
Lo Turco and Maggioni (2012), based on the panorama of Italian manufacturing companies, claim that the international fragmentation of the production process is to put labour markets of developed economies under pressure. Thus, even if the offshoring may represent an opportunity to encourage and increase the competitiveness of many companies in developed countries, it may also be a too heavy burden to employees of more traditional productive sectors, to the extent that these are the sectors that face a greater competition from countries with very low labour costs, and probably will have to reduce their own labour costs in order to maintain competitiveness (Lo Turco and Maggioni 2012). The results obtained by the authors support this idea. Indeed, Lo Turco and Maggioni (2012) concluded that offshoring to low income countries had a negative impact on the conditional labour demand of Italian companies, particularly companies operating in more traditional sectors. Additionally, offshoring to low income countries had a negative impact (and with reduced significance) on the labour demand in non-traditional sectors only when the authors restricted the analysis to the sub sample of exporting companies. Furthermore, the size of the effect is lower than that obtained for exporting firms of traditional sectors.

Studies that have no or a virtually irrelevant effect of offshoring in the home country labour market are also recurring. Groshen et al. (2005), focusing on the offshoring of American companies, concluded that international sourcing may have contributed to the poor performance of the labour market in terms of employability, but only marginally. The authors argue that "the offshoring of jobs is best seen as another form of import activity" and that "a careful analysis of the effect of recent trade patterns on the U.S. labor market requires that we measure not only the jobs lost to imports but also the jobs created through the production of U.S. exports." (Groshen et al. 2005, 1). Thus the authors concluded that the impact of trade on aggregate U.S. employment is only modest. A similar argument is evidenced by Amiti and Wei (2005), when they argue that the risks associated with international relocation in the service sector in developed economies have been highly exaggerated, not occurring an export of jobs from more industrialized countries to developing countries. In fact, evidence suggests that workers who lose jobs in a particular industry eventually find employment in other growth sectors (Amiti and Wei 2005). Also Michel and Rycx (2012) addressing the impact of materials and business services offshoring on total employment for Belgium in the period 1995-2003 found no remarkable effects in the industries analyzed (58 manufacturing 
industries and 35 services industries). Indeed, the estimations of both static and dynamic labour demand equations reveal that the impact of offshoring on employment is negligible for both the manufacturing sector and the services sector.

Finally, it is noted that there are studies that claim that offshoring has a positive effect in terms of job creation in the home country. Feenstra and Hanson (1996) find that offshoring of activities intensive in unskilled labour potentiate an increase in the relative demand for skilled labour in the home country. One can thus join here the idea that the economy of developed countries can effectively grow with the contribution of new products and processes resulting from international sourcing, which give rise to the creation of new jobs (Bhagwati et al. 2004).

Hijzen and Swaim (2007) analysed the effects of offshoring on industry employment for a sample of 17 high OECD countries (data from Inputoutput tables) taking into account the technology and scale effects of offshoring. The technology effect corresponds to the destruction of jobs resulting from the relocation of part of production activities abroad while the scale effects reflects the creation of jobs resulting from increased industrial production that may result from productivity gains induced by offshoring (Hijzen and Swaim 2007). The authors found that offshoring within the same industry (intermediate consumption imported from the same industry) effectively reduce the labour intensity of production but does not affect the total employment in the same industry. Moreover, the inter-industry offshoring (intermediate inputs imported by an industry from other industries) does not affect the labour intensity of production, but may result in positive effects on the creation of jobs (Hijzen and Swaim 2007). The authors argued that this is because the productivity gains resulting from offshoring are so significant so that the jobs created as a result of a higher sales volume exceed those which were destroyed by the relocation of certain production phases (Hijzen and Swaim 2007).

Whereas existing studies have led to different results regarding the impact of offshoring on the labour market (see Table 1), we can consider that the richness and heterogeneity of existing literature are probably also its main shortcoming, in that the presence of scientific evidence capable of sustaining such different visions regarding offshoring may hinder the understanding of the phenomenon itself. 
Table 1 - Summary of the effects of offshoring on employment

\begin{tabular}{|c|c|c|c|c|c|}
\hline Author (year) & Period & Sample / Country & Dependent Variable & Proxies of offshoring & $\begin{array}{l}\text { Effects of offshoring on } \\
\text { labour demand }\end{array}$ \\
\hline $\begin{array}{c}\text { Feenstra } \\
\text { and Hanson } \\
(1996)\end{array}$ & $\begin{array}{l}1972- \\
1992\end{array}$ & 435 industries / US & $\begin{array}{l}\text { Annual change in } \\
\text { the nonproduction } \\
\text { wage share }\end{array}$ & $\begin{array}{l}\text { Share of imported } \\
\text { intermediate inputs in } \\
\text { the total purchases of } \\
\text { non-energy materials }\end{array}$ & $\begin{array}{l}\text { Positive effect on the } \\
\text { demand for skilled labour }\end{array}$ \\
\hline $\begin{array}{l}\text { Strauss-Kahn } \\
\quad(2004)\end{array}$ & $\begin{array}{l}1977- \\
1993\end{array}$ & $\begin{array}{l}50 \text { manufacturing } \\
\text { industries / France }\end{array}$ & $\begin{array}{l}\text { Share of unskilled } \\
\text { workers in industry }\end{array}$ & $\begin{array}{l}\text { Share of imported } \\
\text { inputs embodied in } \\
\text { production }\end{array}$ & $\begin{array}{l}\text { Negative effect in demand } \\
\text { for unskilled labour }\end{array}$ \\
\hline $\begin{array}{l}\text { Amiti and Wei } \\
\text { (2005) }\end{array}$ & $\begin{array}{l}1995- \\
2001\end{array}$ & $\begin{array}{l}69 \text { manufacturing } \\
\text { industries and } 9 \\
\text { from services / UK }\end{array}$ & $\begin{array}{l}\text { Employment } \\
\text { (thousands) }\end{array}$ & $\begin{array}{c}\text { Share of imported } \\
\text { intermediate inputs in } \\
\text { the total purchases of } \\
\text { non-energy materials; } \\
\text { Broad offshoring. }\end{array}$ & $\begin{array}{l}\text { There is no negative } \\
\text { effect of offshoring on the } \\
\text { growth of employment }\end{array}$ \\
\hline $\begin{array}{l}\text { Groshen et al. } \\
\quad(2005)\end{array}$ & $\begin{array}{l}1997- \\
2003\end{array}$ & U.S. & - & 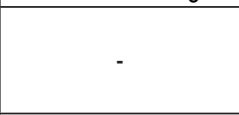 & $\begin{array}{l}\text { The impact of trade on ag- } \\
\text { gregate US employment is } \\
\text { negligible }\end{array}$ \\
\hline $\begin{array}{l}\text { Geishecker } \\
(2006)\end{array}$ & $\begin{array}{l}1991- \\
2000\end{array}$ & $\begin{array}{l}23 \text { sectors from } \\
\text { manufacturing } \\
\text { industry / Germany }\end{array}$ & $\begin{array}{l}\text { The cost share of } \\
\text { low-skilled labour } \\
\text { (composite measure } \\
\text { based on relative } \\
\text { employment and } \\
\text { relative wages) }\end{array}$ & $\begin{array}{l}\text { Share of intermediate } \\
\text { goods imported on } \\
\text { total production of } \\
\text { the industry - narrow/ } \\
\text { broad) }\end{array}$ & $\begin{array}{l}\text { Offshoring affects the } \\
\text { demand for unskilled } \\
\text { labour, benefiting the skill } \\
\text { upgrading in the labour } \\
\text { market }\end{array}$ \\
\hline $\begin{array}{l}\text { Hijzen and } \\
\text { Swaim (2007) }\end{array}$ & $\begin{array}{l}1995- \\
2000\end{array}$ & $\begin{array}{l}17 \text { OECD high } \\
\text { income countries }\end{array}$ & $\begin{array}{l}\text { Employment measu- } \\
\text { red by total persons } \\
\text { engaged }\end{array}$ & $\begin{array}{l}\text { Share of intermediate } \\
\text { goods imported on } \\
\text { the value added of } \\
\text { the industry - narrow } \\
\text { and broad. }\end{array}$ & $\begin{array}{l}\text { No effect or a slightly posi- } \\
\text { tive effect on total sectoral } \\
\text { employment data }\end{array}$ \\
\hline $\begin{array}{l}\text { Cadarso et } \\
\text { al. (2008) }\end{array}$ & $\begin{array}{l}1993- \\
2003\end{array}$ & $\begin{array}{l}93 \text { manufacturing } \\
\text { industries/ Spain }\end{array}$ & $\begin{array}{l}\text { Employment measu- } \\
\text { red by thousands of } \\
\text { yearly worked hours } \\
\text { per sector }\end{array}$ & $\begin{array}{c}\text { Share of intermediate } \\
\text { goods imported on } \\
\text { total production of the } \\
\text { industry; } \\
\text { Narrow Offshoring; }\end{array}$ & $\begin{array}{l}\text { Negative effect on em- } \\
\text { ployment in the home } \\
\text { country }\end{array}$ \\
\hline $\begin{array}{l}\text { Liu and } \\
\text { Nunnenkamp } \\
(2011)\end{array}$ & 1996 & $\begin{array}{l}1,770 \text { manufactu- } \\
\text { ring companies / } \\
\text { Taiwan }\end{array}$ & $\begin{array}{c}\text { Ordinal variable } \\
\text { with three potential } \\
\text { outcome categories } \\
\text { (2 - positive effect; } \\
1 \text { - neutral effect; } 0 \\
\text { - negative effect) } \\
\end{array}$ & $\begin{array}{l}\text { Share of overseas } \\
\text { employees in overall } \\
\text { employees of Taiwa- } \\
\text { nese MNEs }\end{array}$ & $\begin{array}{l}\text { The probability of FDI } \\
\text { have negative effects on } \\
\text { production and employ- } \\
\text { ment increases with the } \\
\text { size of FDI }\end{array}$ \\
\hline $\begin{array}{l}\text { Lo Turco and } \\
\text { Maggioni } \\
\text { (2012) }\end{array}$ & $\begin{array}{l}2000- \\
2004\end{array}$ & $\begin{array}{l}40,479 \text { manufactu- } \\
\text { ring firms / Italy }\end{array}$ & $\begin{array}{l}\text { Number of workers } \\
\text { of the firm operating } \\
\text { in an industry }\end{array}$ & $\begin{array}{l}\text { Share of imported } \\
\text { inputs from high } \\
\text { wage countries and } \\
\text { low wage countries } \\
\text { on the total sales }\end{array}$ & $\begin{array}{l}\text { Negative impact on the } \\
\text { conditional labour demand } \\
\text { particularly in more tradi- } \\
\text { tional sectors }\end{array}$ \\
\hline $\begin{array}{l}\text { Michel and } \\
\text { Rycx (2012) }\end{array}$ & $\begin{array}{l}1995- \\
2003\end{array}$ & $\begin{array}{l}58 \text { manufacturing } \\
\text { industries and } 35 \\
\text { from services / } \\
\text { Belgium }\end{array}$ & $\begin{array}{c}\text { Employment in each } \\
\text { industry measured } \\
\text { by the number of } \\
\text { hours worked per } \\
\text { year }\end{array}$ & $\begin{array}{c}\text { Share of intermediate } \\
\text { goods imported on } \\
\text { total production of the } \\
\text { industry; } \\
\text { Broad offshoring. }\end{array}$ & $\begin{array}{l}\text { Offshoring does not pro- } \\
\text { duce remarkable effects } \\
\text { on job destruction }\end{array}$ \\
\hline
\end{tabular}

Source: Adapted from Crinò (2009, pp. 205-208) and Michel and Rycx (2012, pp. 236-237). 
It should be noted that the findings highlighted in Table 1 as positive, negative or neutral impact of offshoring on home country labour demand result from the interpretation and emphasis given by the authors in their analyses and conclusions. That is, there are studies in which the idea of a negative impact on demand for unskilled labour resulting from the processes of international relocation is highlighted, as in Strauss-Kahn (2004) and Geishecker (2006). In other cases, a greater emphasis is given to a possible positive impact on the demand for skilled labour, as in Feenstra and Hanson (1996) and Hijzen and Swaim (2007). However, the idea that remains is that we are looking at different ways of describing the same phenomenon, given that what is happening is effectively an increase in the demand for skilled labour due to the dynamic gains from international relocation of production stages intensive in unskilled labour (Feenstra and Hanson 1996; Strauss-Kahn 2004; Geishecker 2006; Hijzen and Swaim 2007; Cadarso et al 2008;. Michel and Rycx 2012). As such, if workers see their job destroyed as a result of a process of offshoring, this is because they lack the skills required by the jobs created through scale effects produced by the same production relocation (Hijzen and Swaim 2007).

It is, therefore, pertinent to deepen this theme with a study focusing on the effects of offshoring on the home country's employment, since the diversity of results and conclusions of existing studies open space for extending the debate about the role played by international sourcing and its consequences on employment in developed economies, in a context of an increasingly global and globalized labour market.

\subsection{The Measurement of Offshoring}

Offshoring is a complex phenomenon, and the difficulties inherent to its measurement and impact assessment are proof of that. According to the OECD (2007), in most countries there are no surveys or regular assessments among firms, hindering access to important data for research in this area. It is also difficult to quantify the benefits from increased competitiveness promoted by offshoring not only at the level of firms, as well as consumers / customers, shareholders and employees (OECD 2007). To these obstacles there is still the need to classify as positive or negative the effect of offshoring on a country's economy by taking specific conclusions about the employment outlook. 
Thus, it should be verified what are the most common measures used in the literature to measure offshoring. Table 1 also summarizes the measures used on the empirical studies in this area.

Thus, based on existing literature and methods commonly used to measure offshoring and its impact on the labour market, we find that the first step requires the definition of an empirical measure of offshoring, followed by a multiple regression analysis in which offshoring is included as an independent variable, in order to check its effect, and / or other independent variables (control variables). The dependent variable reflects the labour market - typically the labour demand. The labour demand can be set to reflect, for example, the effects of the independent variables in the demand for skilled or unskilled labour. However, it is relevant to mention the fact that none of the studies analysed focused on the Portuguese case and all of them are based on very old data. In this way we intend to contribute to the enrichment of the existing literature in the area, looking to provide an analysis with a clear focus on the Portuguese economy and using more recent data, allowing more current findings.

As can be seen (Table 1), the majority of existing studies points to a sectoral analysis that can be more or less embracing in terms of sample, and may have some measures of offshoring, with a clear emphasis on the concepts narrow and broad offshoring. Still, there is a trend seen in most studies on the measure of offshoring, whether broad or narrow - the values concerning the variable offshoring are usually obtained through the share of imported intermediate goods by an industry on the total value of output of that industry. The scope of data on imports of intermediate goods that are used for measurement of offshoring, that is whether merely include intermediate goods purchased from the same industry abroad or include imports of intermediate goods from all other sectors, will determine whether the measure that is being used is narrow or broad.

Narrow offshoring, defined by Feenstra and Hanson (1996) or intra-industry offshoring according to Hijzen and Swaim (2007), is restricted to inputs purchased abroad which are of the same type as that produced by the same industry in the domestic market (Cadarso et al. 2008.), that is, inputs purchased by firms in a particular industry from companies in the same industry in another country, usually as a percentage of the total output of the industry in the same period - as in Strauss-Kahn (2004), Geishecker (2006), Cadarso et al. (2008) or Michel and Rycx (2012). 
However, there are other ways of measuring offshoring usually used, also resorting to imports of intermediate inputs but as a percentage of total purchases of non-energy inputs, as in Feenstra and Hanson (1996) or Amiti and Wei (2005), or as a share of the value added in the industry, such as in Hijzen and Swaim (2007). It is noteworthy that studies like those of Strauss-Kahn (2004), Geishecker (2006), or Hijzen and Swaim (2007), use either the narrow offshoring measure but also that of broad offshoring - or inter-industry offshoring, according to Hijzen and Swaim (2007) - considering the imported inputs from all sectors of activity. Other authors, such as Michel and Rycx (2012), choose to use only the broad offshoring or only the narrow offshoring in the case of Cadarso et al. (2008).

\section{Methodology}

\subsection{Model Specification and Definition of Variables}

The present work analyses the impact of international sourcing or offshoring on employment in the Portuguese economy, trying to understand whether this phenomenon has a positive or negative effect on employment. As previously shown, the analysis of most existing studies use data at the sector level, so this will also be our approach. Thus, taking into account that the present study, like Cadarso et al. (2008) and Michel and Rycx (2012), intends to focus on the link between offshoring and employment at the sectoral level, we will use the same method, which does not differ much from what is usually carried out in the existing literature - a labour demand function extended to include the variable related to offshoring:

$$
L_{i t}=\alpha_{1} Y_{i t}+\alpha_{2} W_{i t}+\alpha_{3} O f f_{i t}+\left(\varepsilon_{i}+u_{i t}\right)
$$

Where $L$ represents employment, $Y$ the output, $W$ the labour costs, and Off is the variable related to offshoring. Similarly to Cadarso et al. (2008) all these variables are in logarithms. Finally, $\varepsilon$ represent sector-specific (time-invariant) effects and $u$ respect to the error term. ${ }^{1}$

${ }^{1}$ Subscripts i and $t$ refer, respectively, to the sector/industry and the year. 
In order to take into account potential dynamic links between the variables, the static labour demand given by Equation (1) can be adjusted to include a dynamic component, as is also done in Cadarso et al. (2008):

$$
L_{i t}=\alpha_{0} L_{i t-1}+\alpha_{1} Y_{i t}+\alpha_{2} W_{i t}+\alpha_{3} O f f_{i t}+\left(\varepsilon_{i}+u_{i t}\right)
$$

Regarding the dependent variable $L$, this is usually measured by the number of workers or by the worked hours. Similarly to Cadarso et al. (2008) and Michel and Rycx (2012) it is measured by the total worked hours per sector (millions). Concerning the explanatory variables, and starting with the output $Y$, similarly to Michel and Rycx (2012) we use the value added of each industry (in millions of national currency), deflated by Price levels of gross output by industry using 1995 as the base year. Like Cadarso et al. (2008), labour costs $(W)$ represent the wage rate per worked hour and are obtained by deflating the Labour compensation by industry (in millions of national currency) by Price levels of gross output for each industry using 1995 as the base year and dividing this by the total worked hours at industry-level. Finally, similarly to Geishecker (2006) and Hijzen and Swaim (2007) two alternative measures of offshoring are used: intra-industry (the ratio between the imports of intermediate goods by a given industry from the same industry and their value added - narrow offshoring) and inter-industry (defined by the ratio of imports of intermediate goods by an industry from all other industries and their value added - broad offshoring). For a detailed analysis of these two measures see Section 2.2. The independent variables, the respective proxies, and the expected effect on labour demand are synthetized on Table 2.

Table 2 - Explanatory variables

\begin{tabular}{|l|l|l|c|}
\hline \multicolumn{2}{|c|}{ Variables } & \multicolumn{1}{|c|}{ Proxy } & $\begin{array}{c}\text { Expected impact on } \\
\text { labour demand }\end{array}$ \\
\hline \multirow{2}{*}{ Offshoring } & Offn & $\begin{array}{l}\text { Narrow offshoring (ratio between the imports of intermediate goods } \\
\text { by a given industry from the same industry and their value added) }\end{array}$ & \\
\cline { 2 - 4 } & Offb & $\begin{array}{l}\text { Broad offshoring (ratio of imports of intermediate goods by an } \\
\text { industry from all other industries and their value added) }\end{array}$ & $+/-$ \\
\hline Output & Y & Value added of each industry in constant prices & + \\
\hline Labour costs & W & Real wage rate per worked hour & + \\
\hline
\end{tabular}

Source: Own elaboration 
The impact of offshoring on total employment is ambiguous since as Ahn et al. (2008) highlight it is expected that the relocation of unskilled-labour intensive processes (usually to unskilled-labour abundant countries) affects differently the home country's demand for skilled and unskilled labour: the relative demand for unskilled labour will decrease and the relative demand for skilled labour will increase. Accordingly, the overall effect can not be anticipated. Concerning the expected impact of the variables Output and Labour costs on labour demand, as stated by Michel and Rycx (2012) theory predicts a positive and negative relationship, respectively.

\subsection{Data and Brief Descriptive Analysis}

Data for the variables of the model are entirely coming from Input-Output tables and Socio Economic Accounts for the Portuguese economy between the years 1995 and 2009 provided by the World Input-Output Database - WIOD - (Timmer, 2012) (data accessed on April 2015).

Similarly to other studies, such as Geishecker (2006), Cadarso et. al. (2008) or Lo Turco and Maggioni (2012), 14 sectors of economic activity in Portugal are analysed. The descriptive statistics of the variables are presented in Table 3. In turn, the averages by sector are shown in Table Al in the Appendix.

Table 3 - Descriptive Statistics

\begin{tabular}{|l|c|r|r|r|r|}
\hline \multicolumn{2}{|c|}{ Variables } & \multicolumn{1}{c|}{ Mean } & \multicolumn{1}{c|}{ Minimum } & \multicolumn{1}{c|}{ Maximum } & \multicolumn{1}{c|}{ Std. Deviation } \\
\hline Worked hours (millions) & L & 118.232 & 1.269 & 499.263 & 96.984 \\
\hline Wage rate per hour (national currency) & W & 9.275 & 3.428 & 103.534 & 9.559 \\
\hline $\begin{array}{l}\text { Value added (in million of national cur- } \\
\text { rency) }\end{array}$ & Y & 1169.050 & 7.300 & 2596.458 & 635.261 \\
\hline Narrow offshoring (\%) & Offn & 9.699 & 0.619 & 27.888 & 7.886 \\
\hline Broad offshoring (\%) & Offb & 15.092 & 4.426 & 81.542 & 17.137 \\
\hline
\end{tabular}

Source: own calculations. 
Regarding the dependent variable, Worked hours, it presents a global average of 118. Sector $17 \mathrm{t} 18$ (Textiles and textile) is the one with the highest average (410), while sector 23 (Coke, refined petroleum and nuclear fuel) is the one with the smallest average (2).

Concerning the explanatory variables, in the case of value added the global average is 1169. Similarly to the Worked hours variable, the sector with the highest average is sector $17 \mathrm{t} 18$ and the sector with the smallest average is sector 23. Relative to the Wage rate, its global average is about 9 while the sector with the highest average is sector 23 and the sector with the smallest average is sector 19 (Leather, leather and footwear).

Finally, regarding the measures of offshoring, sector 23 is the one which present the highest average for the Broad offshoring (74\%), which is justified by the fact that its area of activity is highly dependent on imports, but the smallest average with regard to the Narrow offshoring (1.3\%). In turn, sector $27 \mathrm{t} 28$ (Basic metals and fabricated metal) presents the smallest average regarding the Broad offshoring (5\%) and sector 30t33 (Electrical and optical equipment) presents the highest average for the Narrow offshoring (22.4\%). In regard to Broad offshoring there are very great differences between sectors, translating into a high standard deviation of this variable.

More than the global average of variables it is important to understand its evolution over the period under analysis, particularly for the dependent variable (Figure 1) and the main independent variables related to offshoring (Figure 2 and 3 ).

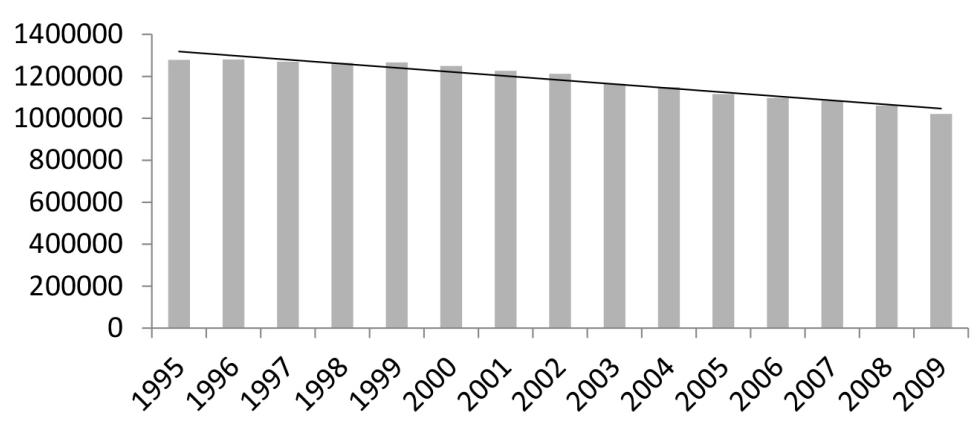

Figure 1 - Employment - worked hours

Source: Own elaboration. 
As evidenced by Figure 1, the number of worked hours shows a downward trend. Rather, the two offshoring measures show an increasing trend.

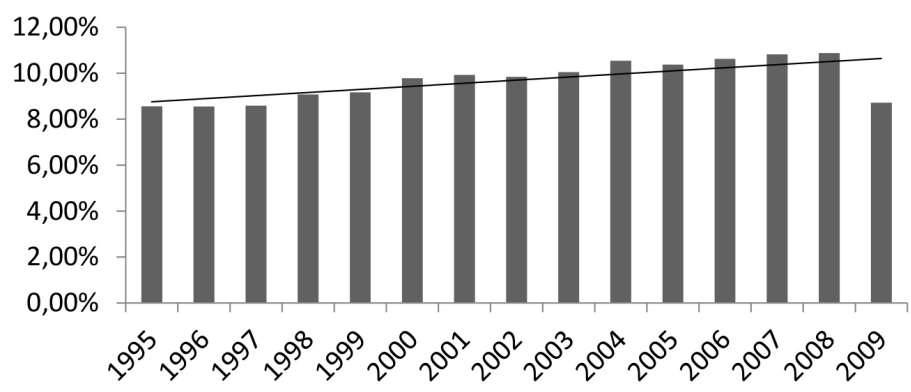

Figure 2 - Narrow offshoring

Source: Own elaboration.

Note that the increasing trend is most obvious in the case of the narrow offshoring (Figure 2). Excluding the year 2009, narrow offshoring increases from $8.55 \%$ in 1995 to $10.88 \%$ in 2008, while broad offshoring presents a more irregular path (Figure 3). Broad offshoring shows a slight decrease between 1995 and 1998 (from 14.09\% to 13.64\%). From 1998 to 2000 Broad offshoring increased about 2 percentage points to $15.9 \%$. Between 2000 and 2007 Broad offshoring remained relatively stable and in 2008 increased 1.3 percentage points (reaching the highest value of $17.29 \%)$.

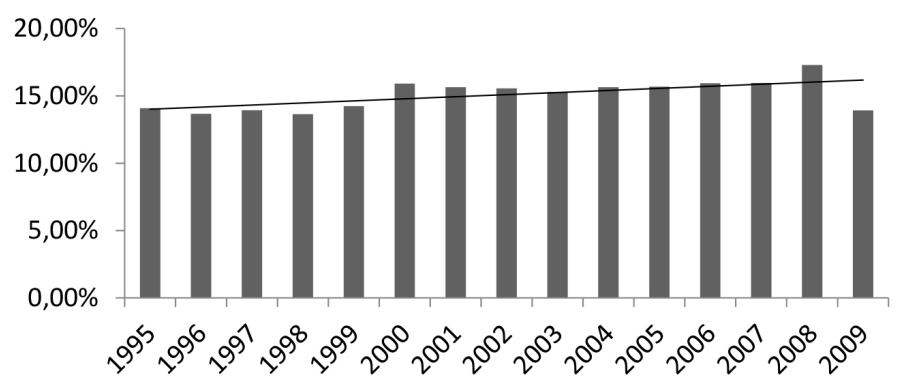

Figure 3 - Broad offshoring

Source: Own elaboration. 
Note that the opposite trend evolution of employment and offshoring variables may suggest the existence of a negative relationship between the two variables.

\subsection{Contextualization of the Portuguese Economy in the 1995-2009 Period}

In the 15-year period under analysis in the present study, the Portuguese economy experienced important changes. On the one hand, at the end of the 1990s, there was a rapid financial integration due to the participation in the euro area and consequent elimination of currency risk. This participation in the euro area also contributed to an economy characterized by low and stable interest and inflation rates (Banco de Portugal 2009). On the other hand, there was a significant increase in the degree of economic integration, both as a result of participation in the European Economic Community and the context of the intensification of the globalization process (Banco de Portugal, 2009), especially since the beginning of the 21 st century. This economic integration is reflected in the degree of openness of the economy, measured by trade (exports and imports) as a \% of GDP, which according to World Bank data reached 54\% in 1993 and 61\% in 2009, having reached a maximum of $72 \%$ in 2008.

Furthermore, in structural terms the Portuguese economy has experienced some changes. In particular, there has been an increase in the weight of services, both in terms of employment and production, by reducing the weight of industry and, to a lesser extent, the weight of agriculture (Banco de Portugal 2009), which is also typical of developed economies. In addition, according to Banco de Portugal (2009), as a result of the aforementioned intensification of the globalization process in the 2000s due to the growing integration of Asian economies, particularly China, in world trade, Portugal experienced a loss of competitiveness in the low-tech sectors (sectors where traditionally presented comparative advantage). On the other hand, although in the post-accession to the European Community in 1986 and especially until the mid-1990s the Portuguese economy received high FDI inflows, ${ }^{2}$ entry into the European Union of Central and Eastern European countries with a relatively well-educated labour force

2 An important share of this FDI was export-oriented and some projects were directed to mediumhigh technology sectors (e.g. motor vehicles) (Banco de Portugal (2009). 
has also put significant pressure on the Portuguese economy in terms of competition in medium-high technology sectors (Banco de Portugal 2009).

Regarding FDI net inflows they increased from USD 685 million in 1995 to USD 5579 million in 2009, representing an average annual growth rate of $15 \%$. In turn, FDI net outflows rose from USD 688 million to USD 3 556 million, which represents an average annual growth of 12\% (World Bank data). It should also be noted that during the last ten years of the period under analysis there was a strong slowdown in the economy. In fact, according to World Bank data, between 1995 and 1999 Portugal recorded an average GDP growth rate of $4.2 \%$ per year, while in the period 2000-2004 this growth stood at 1.5\% and between 2005 and 2009 by only $0.4 \%$ which significantly affected the convergence of the Portuguese economy towards the European Union average. Indeed, up to the 2000s the Portuguese per capita income has converged significantly towards the European Union average and has subsequently begun to diverge gradually (Banco de Portugal 2009). According to World Bank data, Portuguese GDP per capita, PPP (constant 2011 international \$) represented 83\% of the European Union's GDP per capita in 1995, about 86\% in 2000 but only $80 \%$ in 2009 . Despite this fact, the Portuguese economy is classified by the International Monetary Fund as an "advanced economy".

\section{Results and Discussion}

The present econometric analysis focuses on a set of 14 sectors (analysis unit) over 15 years (1995-2009), that is, we have a balanced panel with 210 observations $^{3}$ Similarly to Michel and Rycx (2012) we started by estimating the static labour demand (given by Equation (1)) using OLS and the fixed effects model. ${ }^{4}$ As in the final part of the period under analysis the macroeconomic environment was seriously affected by the international financial crisis of 2008, in all regressions we include a dummy variable - Crisis - to control these effects. This variable assumed the value 1

3 Before the estimation of the model we calculated and analysed the correlation matrix between the relevant variables. Despite the vast majority of correlation coefficients are significant, they are small. The correlation matrix is available on request.

4 According to Wooldridge (2001) two estimation methods can be used do deal with panel data: fixed effects and random effects. However, the results of the Hausman test indicate that fixed effects are more appropriate, so it was the method used. 
in 2008 and 2009 and 0 in the remaining years. Taking into account that we have two proxies for the variable offshoring we estimate two equations. Results are in Table 4.

Table 4 - Static conditional labour demand estimation

\begin{tabular}{|l|c|c|c|c|}
\hline \multirow{3}{*}{ Variables } & \multicolumn{2}{|c|}{ OLS } & \multicolumn{2}{c|}{ Fixed Effects } \\
\cline { 2 - 5 } & $\begin{array}{c}\text { Model I - narrow } \\
\text { offshoring }\end{array}$ & $\begin{array}{c}\text { Model I - broad } \\
\text { offshoring }\end{array}$ & $\begin{array}{c}\text { Model I - narrow } \\
\text { offshoring }\end{array}$ & $\begin{array}{c}\text { Model II - broad } \\
\text { offshoring }\end{array}$ \\
\hline \multirow{2}{*}{ Wages } & $\begin{array}{c}-1.080^{* * *} \\
(0.042)\end{array}$ & $\begin{array}{c}-1.001^{* * *} \\
(0.050)\end{array}$ & $\begin{array}{c}-0.313^{* * *} \\
(0.027)\end{array}$ & $\begin{array}{c}-0.320^{* * *} \\
(0.028)\end{array}$ \\
\hline Output & $\begin{array}{c}0.875^{* * *} \\
(0.077)\end{array}$ & $\begin{array}{c}0.848^{* * *} \\
(0.098)\end{array}$ & $\begin{array}{c}0.136 \\
(0.102)\end{array}$ & $\begin{array}{c}0.135 \\
(0.103)\end{array}$ \\
\hline Offshoring & $0.089^{* * *}$ & $-0.133^{*}$ & 0.030 & 0.053 \\
\hline Crisis & $(0.022)$ & $(0.079)$ & $(0.108)$ & $(0.111)$ \\
\hline R-squared & -0.062 & -0.056 & $-0.067^{*}$ & $-0.068^{*}$ \\
& $(0.053)$ & $(0.050)$ & $(0.034)$ & $(0.033)$ \\
\hline Test F & 0.945 & 0.944 & $104.06^{* * *}$ & $85.97^{* * *}$ \\
\hline Observations & 210 & 210 & 210 & 210 \\
\hline
\end{tabular}

Legend: ${ }^{*} \mathrm{p}<0.1 ;{ }^{* *} \mathrm{p}<0.05 ;{ }^{* * *} \mathrm{p}<0.01$; Standard errors in parentheses; All variables, except Crisis, are in logarithms.

Source: Own estimation using STATA, using robust standard errors.

With regard to the control variables, Wages and Output, they are statistically significant and exhibit the expected signs on the OLS estimation. However, in the fixed effects model only the variable Wages is statistically significant. Additionally, focusing on the results of the fixed effects model, the contemporaneous wage elasticity $(0.313$ and 0.320 , respectively for the model I and model II) belongs to the confidence interval [0.15; 0.75] determined by Hamermesh (1993), as cited in Michel and Rycx (2012, p.238). In turn, the elasticities of labour demand with respect to value-added are 0.136 and 0.135 , respectively for the model I and model II. These results are similar to those obtained by Michel and Rycx (2012) for the manufacturing sector (as is our case) and according to the authors are "broadly in line with earlier findings" (Michel and Rycx 2012, 238). 
With respect to the variable of interest, offshoring, the results of the fixed effects model show that, regardless of the proxy used (Narrow offshoring or Broad offshoring), this variable is not statistically significant. These results are in line with Michel and Rycx (2012)'s findings. Finally, the variable Crisis presents a negative and statistically significant coefficient, as expected.

According to Michel and Rycx (2012), one reason why the impact of offshoring is insignificant may be due to the use of the static labour demand. Indeed, it is important to take into account the persistence of employment by introducing a lagged dependent variable in the regression (Michel and Rycx, 2012), that is, we need to consider a dynamic labour demand. Therefore, we estimated the dynamic labour demand (equation 2 ), by resorting to the OLS, the fixed effects (FE) model and also the Difference Generalized Method of Moments (GMM-DIF) and Systems Generalized Method of Moments (GMM-SYS), like Cadarso et al. (2008) and Michel and Rycx (2012). In fact, according to Arellano and Bond (1991), as cited in Cadarso et al. (2008), the existence of a lagged dependent variable among the regressors generates problems in OLS estimations, so the GMM-DIF and GMM-SYS might be more suitable than simple OLS. There are two estimations for each method, in order to evaluate the two alternative proxies for offshoring, and the results are shown in Table 5.

The application of the GMM methods requires the choice of appropriate instruments. This choice is based on assumptions about the variables justified by economic theory (Cadarso et al. 2008). In this way, and similar to Cadarso et al. (2008) we assume that Employment and Output are endogenous, Wages is predetermined and Offshoring is exogenous. GMM estimators assume that "the only available instruments are internal - based on lags of the instrumented variables" (Roodman 2006, 14). However, as reported by Mileva (2007), occasionally the lags of the variables in levels are not good instruments for the first-difference regressors, so in this case it should be used the "System GMM" which tends to increase efficiency. It should be noted that GMM estimators can generate problems related to the existence of too many instruments, particularly when the panel is reduced in terms of the number of groups, ${ }^{5}$ which occur in our case (only 14 groups). According to Mileva $(2007,6)$, "the rule of thumb is to keep the number of instruments less than or equal to the number of groups".

5 These estimators are designed for panels with few time periods (T) and large number of individuals/ groups (N) (Roodman 2006). 
Although we have followed the strategy usually indicated to decrease the number of instruments and that is to use only the second lag of the endogenous variables as instruments, in our case the number of instruments continues superior to the number of groups in both GMM-DIF and GMMSYS. Although this does not compromise coefficient estimates, it will weaken the Sargan/Hansen test because it can lead to unrealistic $p$ values of 1.000 (Roodman 2006), although this was not the case in our case.

Table 5 - Dynamic conditional labour demand estimation

\begin{tabular}{|c|c|c|c|c|c|c|c|c|}
\hline \multirow[b]{2}{*}{ Variable } & \multicolumn{2}{|c|}{ OLS } & \multicolumn{2}{|c|}{ Fixed Effects } & \multicolumn{2}{|c|}{ Difference GMM } & \multicolumn{2}{|c|}{ System GMM } \\
\hline & $\begin{array}{l}\text { Model } \\
\text { I narrow } \\
\text { offshoring }\end{array}$ & $\begin{array}{l}\text { Model II } \\
\text { broad } \\
\text { offshoring }\end{array}$ & $\begin{array}{c}\text { Model I } \\
\text { narrow } \\
\text { offshoring }\end{array}$ & $\begin{array}{l}\text { Model II } \\
\text { broad } \\
\text { offshoring }\end{array}$ & $\begin{array}{c}\text { Model I } \\
\text { narrow } \\
\text { offshoring }\end{array}$ & $\begin{array}{c}\text { Model II } \\
\text { broad } \\
\text { offshoring }\end{array}$ & $\begin{array}{c}\text { Model I } \\
\text { narrow } \\
\text { offshoring }\end{array}$ & $\begin{array}{l}\text { Model II } \\
\text { broad } \\
\text { offshoring }\end{array}$ \\
\hline L1.Emp & $\begin{array}{c}0.879^{\star \star \star} \\
(0.080)\end{array}$ & $\begin{array}{c}0.885^{\star \star \star} \\
(0.076)\end{array}$ & $\begin{array}{c}0.680^{\star \star \star} \\
(0.061)\end{array}$ & $\begin{array}{c}0.681^{\star \star \star} \\
(0.065)\end{array}$ & $\begin{array}{c}0.758^{\star \star *} \\
(0.089)\end{array}$ & $\begin{array}{c}0.771^{\star * *} \\
(0.093)\end{array}$ & $\begin{array}{c}0.876^{\star \star \star} \\
(0.010)\end{array}$ & $\begin{array}{c}0.892^{\star \star \star} \\
(0.019)\end{array}$ \\
\hline Wages & $\begin{array}{l}-0.126 \\
(0.092) \\
\end{array}$ & $\begin{array}{l}-0.124 \\
(0.086)\end{array}$ & $\begin{array}{c}-0.158^{\star \star \star} \\
(0.011)\end{array}$ & $\begin{array}{c}-0.156^{* \star *} \\
(0.009)\end{array}$ & $\begin{array}{c}-0.117^{\star \star \star} \\
(0.035)\end{array}$ & $\begin{array}{c}-0.117^{\star \star \star} \\
(0.031)\end{array}$ & $\begin{array}{c}-0.106^{\star \star \star} \\
(0.030)\end{array}$ & $\begin{array}{c}-0.103^{\star \star \star} \\
(0.031)\end{array}$ \\
\hline Output & $\begin{array}{c}0.115 \\
(0.071)\end{array}$ & $\begin{array}{l}0.119^{*} \\
(0.072)\end{array}$ & $\begin{array}{c}0.234^{\star \star *} \\
(0.045)\end{array}$ & $\begin{array}{c}0.230^{\star \star *} \\
(0.049)\end{array}$ & $\begin{array}{c}0.011 \\
(0.038)\end{array}$ & $\begin{array}{l}-0.005 \\
(0.037)\end{array}$ & $\begin{array}{c}0.136^{\star \star *} \\
(0.024)\end{array}$ & $\begin{array}{c}0.131^{\star \star *} \\
(0.023)\end{array}$ \\
\hline Offshoring & $\begin{array}{c}0.002 \\
(0.007) \\
\end{array}$ & $\begin{array}{l}0.016^{* *} \\
(0.008)\end{array}$ & $\begin{array}{l}-0.034 \\
(0.027) \\
\end{array}$ & $\begin{array}{l}-0.019 \\
(0.046) \\
\end{array}$ & $\begin{array}{c}0.032 \\
(0.025) \\
\end{array}$ & $\begin{array}{l}0.073^{*} \\
(0.036) \\
\end{array}$ & $\begin{array}{l}-0.007 \\
(0.015)\end{array}$ & $\begin{array}{c}0.028 \\
(0.028)\end{array}$ \\
\hline Crisis & $\begin{array}{c}-0.027^{\star \star \star} \\
(0.008)\end{array}$ & $\begin{array}{c}-0.027^{\star \star \star} \\
(0.009)\end{array}$ & $\begin{array}{c}-0.037^{* \star *} \\
(0.007)\end{array}$ & $\begin{array}{c}-0.036^{* * *} \\
(0.007)\end{array}$ & $\begin{array}{c}-0.029^{\star \star \star} \\
(0.003)\end{array}$ & $\begin{array}{c}-0.032^{* \star *} \\
(0.004)\end{array}$ & $\begin{array}{c}-0.028^{\star * *} \\
(0.009)\end{array}$ & $\begin{array}{c}-0.028^{\star \star *} \\
(0.010)\end{array}$ \\
\hline R-Squared & 0.997 & 0.997 & & & & & & \\
\hline F-Satistic & & & $682.17^{* * *}$ & $1383.83^{* * *}$ & & & & \\
\hline $\begin{array}{c}\text { Groups/Instru- } \\
\text { ments }\end{array}$ & & & & & $14 / 17$ & $14 / 17$ & $14 / 34$ & $14 / 34$ \\
\hline $\begin{array}{l}\text { Sargan test } \\
\text { (Sarganp) }\end{array}$ & & & & & $\begin{array}{c}22.62 \\
(0.031)\end{array}$ & $\begin{array}{c}21.93 \\
(0.038)\end{array}$ & $\begin{array}{c}83.74 \\
(0.000)\end{array}$ & $\begin{array}{c}82.89 \\
(0.000)\end{array}$ \\
\hline $\begin{array}{c}\text { Hansen test } \\
\text { (Hansenp) }\end{array}$ & & & & & $\begin{array}{c}13.15 \\
(0.358)\end{array}$ & $\begin{array}{c}12.33 \\
(0.419)\end{array}$ & $\begin{array}{c}11.56 \\
(0.997)\end{array}$ & $\begin{array}{c}11.50 \\
(0.998)\end{array}$ \\
\hline Observations & 196 & 196 & 196 & 196 & 182 & 182 & 196 & 196 \\
\hline
\end{tabular}

Legend: ${ }^{*} \mathrm{p}<0.1 ;{ }^{* *} \mathrm{p}<0.05 ;{ }^{* * *} \mathrm{p}<0.01$; Standard errors in parentheses; All variables, except Crisis, are in logarithms. GMM-DIF (one step) using $L_{t-2}, Y_{t-2}$ and $W_{t-1}$ as instruments.

Source: own calculations with STATA, using robust standard errors. 
Although the results of the Sargan and Hansen tests suggest that the instruments used in the GMM estimation are weak, they suggest a better performance of the Difference GMM. In addition, as referred to by Baum (2013), the OLS estimation tends to skew the coefficient of the lagged dependent variable upward and the fixed effects estimation tends to skew this coefficient downward, so consistent estimates must be between these two values (0.680 and 0.879 or 0.681 and 0.885$)$. This occurs with the GMM-DIF estimates but not with those obtained by GMM-SYS.

Focusing on the results of GMM-DIF estimations, and with respect to control variables, the coefficients of the variables Wages and Output exhibit the expected signs (respectively negative and positive), but only the variable Wages is statistically significant. That is, an increase in wages per worked hour will reduce demand for labour. Furthermore, the variable Crisis presents a negative and statistically significant coefficient, as expected.

With regard to the variable Offshoring, the Broad offshoring presents a positive and statistically significant relationship with labour demand, that is, the use of offshoring appears to be contributing to increased employment in Portugal, although the impact is relatively small. Relative to the Narrow offshoring variable, similarly to the static analysis results under fixed effects it is also not statistically significant. The positive relationship between Broad offshoring and employment, in the Portuguese case, suggests that the number of jobs created due to increased sales resulting from productivity gains induced by offshoring outweigh the destruction of jobs resulting from the relocation of some production activities to foreign countries.

\section{Conclusions}

Starting from the negative idea that is generally associated with offshoring in developed economies, which is generally considered one of the causes underlying the increase in unemployment due to the relocation of jobs abroad, this paper seeks to be a contribution to the study of the effects of that phenomenon on the labour market. In this case, we focuses on the Portuguese case, about which there are no studies that refer specifically to 
this issue, in order to try to understand whether there is reason to point to offshoring as one of the causes for the rise in unemployment over the last decade.

Through a panel data for 14 industrial sectors of the Portuguese economy between 1995 and 2009, the results obtained are similar to the results of Hijzen and Swaim (2007) for 17 OECD high income countries, which indicate there is evidence that offshoring seems to have positive effects on labour demand. That is, the estimations of the dynamic labour demand equations (through a GMM-DIF model) indicate that broad offshoring may contribute to the creation of jobs. This may suggest that, as stated by Lo Turco and Maggioni (2012), offshoring may represent an opportunity to encourage and increase the competitiveness of companies in developed countries. In this way offshoring contributes to the creation of a greater number of jobs than the number of jobs that are relocated to foreign countries.

It must be noted that this study focused only on industry sectors and does not cover the services sector. Thus, more and better lessons could arise by a more comprehensive study of the domestic economic outlook, in what may be appointed as both a limitation of the present work and a suggestion for future research in this area. In particular, future work should aim to include a larger number of sectors in order to allow a more robust use of the GMM method. Additionally, our focus was on the effects of offshoring on total employment so our results may hide possible differences in the demand for different types of workers (skilled or unskilled workers). In fact, as already mentioned, the literature is consistent on the idea that the more skilled workers tend to be positively affected by offshoring, verifying the contrary in workers with lower levels of qualifications, who face higher probability of seeing their jobs destroyed. Therefore, a research focusing specifically on this differential of skills, wages and how offshoring affects it would be a relevant development of the literature on offshoring concerning the Portuguese economy. It is also a relevant issue for the correct definition of policies aiming at combating the potential negative effects of offshoring. 


\section{References}

Ahn, S., Fukao, K., and Ito, K. 2008. "The Impact of Outsourcing on the Japanese and South Korean Labour Markets: International Outsourcing of Intermediate Inputs and Assembly in East Asia”. Center on Japanese Economy and Business - Working Paper Series 280, 1-55.

Aizenman, J., and Marion, N. 2004. "The merits of horizontal versus vertical FDI in the presence of uncertainty". Journal of International Economics 62 (1): 125-148.

Alajääskö, P. 2009. Features of International Sourcing in Europe in 2001-2006. Obtained from Eurostat - accessed in 1 October 2013: http://epp.eurostat.ec.europa.eu/cache/ITY OFFPUB/KS-SF-09-073/EN/KS-SF09-073-EN.PDF

Alajääskö, P., Nielsen, P. B., Rikama, S., and Sisto, J. 2011. Global value chains - international sourcing to China and India. Obtained from Eurostat - accessed in 1 October 2013: http://epp.eurostat.ec.europa.eu/statistics_explained/index.php/Global_value_chains__ international_sourcing to China and_India

Amiti, M., and Wei, S.-J. 2005. “Fear of service outsourcing: is it justified?” Economic Policy 20 (42): 307-347.

Banco de Portugal. 2009. The Portuguese Economy in the Context of Economic, Financial and Monetary Integration, Economics and Research Department Banco de Portugal, Lisboa.

Baum, C. 2013. Dynamic Panel Data estimators. Applied Econometrics, Boston College.

Bhagwati, J., Panagariya, A. P., and Srinivasan, T. N. 2004. “The Muddles over Outsourcing”. Journal of Economic Perspectives 18 (4): 93-114.

Cadarso, M. Á., Gómez, N., López, L. A., and Tobarra, M. Á. 2008. "The EU enlargement and the impact of outsourcing on industrial employment in Spain, 1993-2003”. Structural Change and Economic Dynamics 19: 95-108.

Crinò, R. 2009. “Offshoring, Multinationals and Labour Market: A Review of the Empirical Literature”. Journal of Economic Surveys 23 (2): 197-249.

Dey, M., Houseman, S. N., and Polivka, A. E. 2012. “Manufacturers' Outsourcing to Staffing Services”. Industrial and Labour Relations Review 65 (3): 533-559.

Doh, J. P. 2005. “Offshore Outsourcing: Implications for International Business and Strategic Management Theory and Practice". Journal of Management Studies 42 (3): 695-704.

Dunning, J. H. 1988. "The Eclectic Paradigm of International Production: A Restatement and Some Possible Extensions". Journal of International Business Studies 19 (1): 1-31.

Dunning, J. H. 2000. "The eclectic paradigm as an envelope for economic and business theories of MNE activity”. International Business Review 9: 163-190.

Dunning, J. H., and Lundan, S. M. 2008. Multinational Enterprises and the Global Economy. Cheltenham, UK: Edward Elgar.

Feenstra, R. C., and Hanson, G. H. 1996. "Globalization, Outsourcing, and Wage Inequality". American Economic Review 86 (2): 240-245.

Geishecker, I. 2006. “Does Outsourcing to Central and Eastern Europe Really Threaten Manual Workers' Jobs in Germany?" World Economy 29 (5): 559-83.

Groshen, E. L., Hobijn, B., and McConnell, M. M. 2005. "U.S. Jobs Gained and Lost through Trade: A Net Measure". Current Issues in Economics and Finance 11 (8): 1-7.

Hijzen, A., and Swaim, P. 2007. "Does offshoring reduce industry employment?" National Institute Economic Review 201 (1): 86-96.

Horgos, D. 2009. "Labour market effects of international outsourcing: How measurement matters". International Review of Economics and Finance 18 (4): 611-623.

Linares-Navarro, E., Pla-Barber, J., and Villar-García, C. 2009. "Productivity, Profitability and Employment: Exploring the Different Effects of the Offshoring Mode". GCG: Revista de Globalización, Competitividad and Gobernabilidad 3 (3): 126-141. 
Liu, W.-H., and Nunnenkamp, P. 2011. "Domestic Repercussions of Different Types of FDI: Firm-Level Evidence for Taiwanese Manufacturing”. World Development 39 (5): 808-823

Lo Turco, A., and Maggioni, D. 2012. "Offshoring to High and Low Income Countries and the Labour Demand. Evidence from Italian Firms". Review of International Economics 20 (3): 636-653.

Michel, B., and Rycx, F. 2012. "Does offshoring of materials and business services affect employment? Evidence from a small open economy". Applied Economics 44 (2): 229-251.

Mileva, E. 2007. Using Arellano - Bond Dynamic Panel GMM Estimators in Stata. Economics Department, Fordham University.

Neureiter, M., and Nunnenkamp, P. 2010. "Outsourcing Motives, Location Choice and Labour Market Implications: An Empirical Analysis for European Countries”. KYKLOS 63: 206-230.

Nguyen, H., and Lee, Y.-F. L. 2008. "International outsourcing in emerging and developed economies: an empirical study”. Journal of International Business Research 7 (3): 53-62.

OECD. 2007. Offshoring and Employment: Trends and Impacts. Paris: OECD.

Roodman, D. 2006. "How to do xtabond2: an introduction to "Difference" and "System" GMM in Stata". Center for Global Development Working Paper Number 103.

Strauss-Kahn, V. 2004. "The Role of Globalization in the Within-Industry Shift Away from Unskilled Workers in France". Challenges to Globalization: Analyzing the Economics (pp. 209-233). Chicago and London: University of Chicago Press.

Timmer, M. 2012. "The World Input-Output Database (WIOD): Contents, Sources and Methods". WIOD Working Paper Number 10, 1-73.

UNCTAD. 2004. World Investment Report - The Shift Towards Services. New York and Geneva: United Nations.

Wooldridge, J.M. 2001. "Econometric Analysis of Cross Section and Panel Data" The MIT Press Cambridge, Massachusetts. 


\section{Appendix}

Table Al - Averages by sector

\begin{tabular}{|l|c|c|c|c|c|c|}
\hline \multicolumn{1}{|c|}{ Sector } & Code & $\begin{array}{c}\text { Employment } \\
\text { (Worked hours) }\end{array}$ & Value Added & Wages & $\begin{array}{c}\text { Narrow } \\
\text { offshoring }\end{array}$ & $\begin{array}{c}\text { Broad } \\
\text { Offshoring }\end{array}$ \\
\hline Food, beverages and tobacco & 15 t16 & 207.708 & 1944.605 & 5.279 & 0.017 & 0.110 \\
\hline Textiles and textile & $17 t 18$ & 409.629 & 2321.384 & 4.459 & 0.115 & 0.054 \\
\hline Leather, leather and footwear & 19 & 114.257 & 597.165 & 3.633 & 0.115 & 0.073 \\
\hline Wood and of wood and cork & 20 & 92.657 & 649.136 & 5.688 & 0.047 & 0.083 \\
\hline Pulp, paper, printing and publishing & 21 t22 & 90.140 & 1478.050 & 9.023 & 0.076 & 0.063 \\
\hline $\begin{array}{l}\text { Coke, refined petroleum and } \\
\text { nuclear fuel }\end{array}$ & 23 & 2.159 & 86.952 & 30.024 & 0.013 & 0.740 \\
\hline Chemicals and chemical & 24 & 42.290 & 1069.204 & 13.208 & 0.165 & 0.057 \\
\hline Rubber and plastics & 25 & 45.888 & 580.005 & 7.408 & 0.034 & 0.212 \\
\hline Other non-metallic mineral & 26 & 123.399 & 1730.269 & 7.826 & 0.018 & 0.089 \\
\hline Basic metals and fabricated metal & $27 t 28$ & 170.308 & 1586.211 & 6.501 & 0.213 & 0.050 \\
\hline Machinery, Nec & 29 & 82.001 & 769.005 & 6.839 & 0.086 & 0.158 \\
\hline Electrical and optical equipment & $30+33$ & 85.618 & 1586.738 & 13.169 & 0.224 & 0.123 \\
\hline Transport equipment & $34 t 35$ & 70.486 & 1345.816 & 12.790 & 0.220 & 0.141 \\
\hline Manufacturing nec; recycling & $36+37$ & 118.701 & 622.162 & 3.999 & 0.017 & 0.158 \\
\hline Total & & 118.232 & 1169.05 & 9.275 & 0.097 & 0.151 \\
\hline
\end{tabular}

Source: Authors calculations. 